\title{
INTEGRAL ADAPTATION TO CLIMATE CHANGE IN COASTAL ZONES: OPPORTUNITIES AND LIMITS - RIOLAGARTOS BIOSPHERE RESERVE, YUCATÁN, MÉXICO
}

\author{
BERTHA NELLY CABRERA-SÁNCHEZ, JOEL F. AUDEFROY, \\ MILTON MONTEJANO-CASTILLO \& HÉCTOR MANUELGALVÁN-ALCOCER \\ Instituto Politécnico Nacional ESIA TEC, México
}

\begin{abstract}
Climate change on the planet is irreversibly affecting all continents to a greater or lesser extent. Consequently, populations settled in rural, urban and coastal areas must undergo an inevitable adaptation process due to the risks and vulnerabilities that prevail in each region. However, adaptation opportunities in coastal zones are shaped by social, economic and environmental problems that influence local adaptation capacity. In this research, the analyzed case study comprises the communities located along the Rio Lagartos Biosphere Reserve, in Yucatán, México, where habitability conditions have been seriously threatened by climate change affecting local dwellings, the natural landscape, urban equipment and infrastructure, among others. As a result of this research, the effects of such threats were identified and sustainable development indicators are suggested as part of a more integral approach for policy makers to promote adaptation and reinforce the habitability conditions of coastal, rural and urban areas. The incorporation of strategies for optimizing resources to make local livelihoods more efficient and sustainable should be part of such policy agenda.
\end{abstract}

Keywords: integral adaptation, risk, sustainable development indicators, habitability.

\section{INTRODUCTION}

Humanity has perceived climate as a threat since time immemorial. Millions of years have gone by and human beings continue to adapt to the climate. Our ancestral awareness of climate has been tremendously helpful in identifying climate cycles, which today are studied scientifically. In more recent years, global concerns raised throughout the world have sounded the warning bell on various activities carried out by humankind that directly affect the climate. Researchers have begun to enumerate and explore the many problems triggered by climate change, some devoted to describing the problem, others promoting methodologies for reducing the impact of climate change, and evaluating vulnerabilities and risk. Around the world, organizations of experts have been created to understand, describe, explain and communicate the problem to the general public. Since the first report by the Intergovernmental Panel on Climate Change (IPCC), created in 1988 [1], researchers have been developing scientific, technical and socioeconomic tools to apply to all parts of the world. Widespread interest in exploring the repercussion and possible responses has inspired researchers to work with local populations on the possibility of strengthening development policies in order to reduce the risk of disaster. A global platform for disaster risk reduction was created, making it possible for agents involved in various areas of development to participate in the process. The United Nations Office for Disaster Risk Reduction (UNISDR) [2] first sponsored the Hyogo Framework for Action 2005-2015 [3], which issued the Report of the World Conference on Disaster Reduction in Hyogo, Japan; followed by the Sendai Framework for Disaster Risk Reduction 2015-2030 [4], adopted in the third UN conference on that topic in Sendai, Japan, on March 18, 2015. The framework provides a timely assessment of how to manage needs, as part of a better understanding of disaster risks. International forums have been created open to all countries, among them the Regional 
Platform for Disaster Risk Reduction in the Americas 2009-2017, held in previous years in Panama, Mexico, Chile, Ecuador and Canada. Currently, the United Nations International Strategy for Disaster Reduction (UISDR) [2] serves as a direct liaison between agents involved, addressing the problems of poverty and environmental sustainability at all levels of government. In May 2017, the Global Platform for Disaster Risk Reduction will be held in Cancun, Mexico. The actions taken to date by governments remain global in nature, and have not been carried to the local level, as was intended. Mindful of the rights and obligations entailed in each of these disaster risk reduction frameworks, society at large has become increasingly aware of the problem of climate change - problems that arise when the climate is stable, or altered by external factors, affected by natural or man-made phenomena. To inform governments' stance on climate change, considerable effort has gone into the development of methodologies and strategies for understanding and communicating the situation, in the hopes that governments, specialists and society at large can apply these experiences in the implementation of new proposals for disaster risk reduction.

By the year 2015, the world's population had reached 7.43 billion inhabitants [5]. Cities are contending with the growing problems of exploding population and housing, rampant overuse of land by human activities that include illegal occupation of protected zones, and the reduction of areas available for farming, forestry and livestock, among others. But these activities remain necessary for the development, functioning and survival of entire peoples.

The issue of disasters has been the subject of formal study for almost 30 years, led by researchers such as Cannon [6], Maskrey [7], Wisner et al. [8], and others. The prospects are particularly troubling for the world's coastal regions, as projections indicate rising sea levels that imperil human settlements close to the water's edge.

In Mexico, according to data from the Ministry of the Environment and Natural Resources (SEMARNAT), 17 states border the coast, representing $56 \%$ of the nation's territory. Mexico's coastline measures a total of $11,122 \mathrm{~km}$ on the Pacific side, $7828 \mathrm{~km}$ on the Gulf of California, and $3294 \mathrm{~km}$ on the Gulf of Mexico and Caribbean [9]; hence the concern over communities settled along the coast, which are experiencing a steady rise in population and overcrowding, increasing their vulnerability to natural and man-made phenomena.

Article 66 of Mexico's General Law on Climate Change stipulates that SEMARNAT must create a Special Climate Change Program (PECC) for 2014-2018, with the participation and approval of the Inter-Secretarial Commission on Climate change (CICC), which will establish goals, strategies, actions and targets in the area of climate change [10].

Mexico's Yucatan peninsula was selected for this case study because it has coast both on the Gulf of Mexico and the Caribbean, and 13 of its municipalities have coastline borders. Among these, San Felipe, Rio Lagartos and Tizimin all belong to region V, considered part of the Ría Lagartos Biosphere since 1999, with an area of 60,347 hectares, 82 areas and 71 centiare (see Fig. 1) [11].

This area is frequently subject to threats from natural phenomena like hurricanes and red tide, which have a particularly deleterious effect on the local economy because they are unpredictable and directly affect their livelihood. The local know-how developed by the people has been lost over the generations, and failure to document this knowledge and observation by the people of events in the past, regardless of how frequent, impedes the successful interchange of information on adapting to climate change and facing and reducing disaster risk. A local community might be able to contribute considerably to scientific knowledge in various areas. Dealing with weather and man-made phenomena is not an easy matter, and no one could be more keenly aware of this than the local populace. So, it is their local knowledge and their adaptation and efforts to deal with adversity that can help us identify information from past events useful for surviving future disasters. 

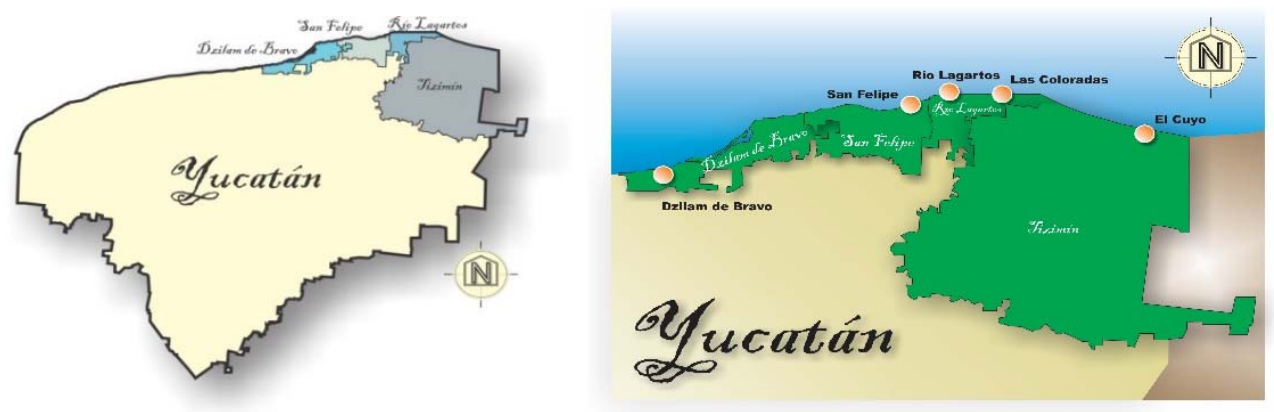

Figure 1: Location of the Ría Lagartos Biosphere, Yucatan, Mexico (INEGI 2010).

\section{SOCIAL VULNERABILITY}

Vulnerability has been defined in a number of ways, some more similar than others, but they always draw on the relationship between space, time and human beings. How can we understand vulnerability, if all human beings are exposed to some extent to present and future events? To explain this, we must take into account capacities, incapacities, changes, levels of adaptation, levels of resilience, degrees of exposure and threats, with regard to a given community (Cardona and Omar [12], Wilches-Chaux [13], Fekete et al. [14]).

Identifying the degree of social vulnerability in a given community entails observing and measuring their livelihood, alimentary security, economic income, social security, education, poverty levels, marginalization, migration and level of social organization, in light of a series of natural and man-made threats that community faces.

In a paper on vulnerability and adaptation in Yucatan [15], researchers stressed the importance of joint work between authorities and inhabitants at the local level, noting that social engagement must be expressed in all areas in order to reduce vulnerability and mitigate the risks faced by coastal areas. Busso [16], cited in that paper, points out the tremendous importance of the world around us - a set of opportunities linked to levels of well-being that individuals can achieve - combined with internal elements such as the quantity, quality and diversity of resources, and assets and capital that can be mobilized to face the threat. This relates directly to a community's response capacity. Macías [17] concurs that vulnerability corresponds to the social relationships between human beings, but also between them and their natural environment.

Human settlements located in coastal areas are more vulnerable to climate change: inhabitants are not unfamiliar with frequent and intense natural phenomena such as hurricanes, tropical storms, norte storm fronts, red tide and other atypical events, but they have become more aware recently of changes in the cycles of rainy and hot seasons. These phenomena not only make them more vulnerable, but also bring other situations they are not as familiar with - the transmission of insect-borne illness like chikungunya, dengue and zika, for example. Their vulnerability is thus exacerbated by the lack of an immediate response, because they do not know how to react. Children, young people and the elderly are the most heavily affected by the chikungunya virus's presence in coastal areas.

Social vulnerability is also reflected in property losses, caused by natural disasters like hurricanes that bring flooding that can sweep away entire homes. 
Understanding the populations of coastal zones is not easy, because their livelihood and way of living revolves around the sea and their alimentary security is at risk. There is an imminent migration of human settlements away from coastal areas inland to more secure locations. The question is whether populations are prepared to receive other inhabitants in critical conditions caused by natural or man-made phenomena.

\section{INTEGRAL ADAPTATION TO CLIMATE CHANGE}

The information that is developed and managed by researchers and other experts gives us a clear picture of the reality inhabitants face when they live in areas severely affected by natural or man-made phenomena. The destruction of homes by earthquakes, tornadoes, hurricanes, volcanic eruptions, tsunamis, landslides, drought, sinkholes, land subsidence, avalanches, electrical and sandstorms, global war, industrialization, use of nuclear plants and weapons, epidemics and other situations, force then to adapt immediately to these conditions in their social, economic, environmental and political surroundings.

The IPCC defines adaptation as follows: "The process of adjustment to actual or expected climate and its effects. In human systems, adaptation seeks to moderate or avoid harm or exploit beneficial opportunities. In some natural systems, human intervention may facilitate adjustment to expected climate and its effects" [1].

Based on this definition, we must adapt empirical, humanitarian or technological focuses to better understand integral adaptation to climate change, incorporating social, environmental and economic factors, among others.

Among the social aspects that need to be considered are the biophysical environment, health, education, housing, infrastructure, urban equipment and services, and population; the economic aspects include employment, income and economic activities; and finally, of the environmental factors, we need to take into account information on water, atmosphere, biodiversity, forest areas, fishing, waste and transportation.

Inhabitants in coastal zones are still dependent on environmental resources, which put them in a more difficult position, economically and socially, to adapt to climate change. For example, San Felipe, Río Lagartos, Las Coloradas and El Cuyo, towns with similar characteristics located close to fishing ports, depend heavily on river fishing for their livelihood, so when these activity is imperiled, their earning capacity also declines. Fishing is a seasonal activity, which means families are more vulnerable to situations such as red tide, which is caused by the presence of certain algae and high concentrations of toxins that are hazardous for the aquatic environment, and causes economic losses for fish farming as well as for fishermen from regions where this phenomenon is prevalent. Testimonies collected from interviews with fishermen reveal that fishing communities can take between six months and a year to recover from red tide, and it also affects inhabitants' health, because a red tide leaves hundreds of dead fish strewn along the water's edge, creating unsanitary conditions and noxious odors as they decompose, polluting air, water and soil all at once. The damage is compounded by complications like respiratory illness and in the worst cases the proliferation of mosquitos, which can transmit viruses like zika or chikunguyna.

The knowledge that coastal inhabitants have accumulated and adapted based on their experiences with natural disasters such as hurricanes is strengthened by and reflected in better social relationships in the community, because of this adaptive response. One recent example of local authorities' interest in improving civil protection on a local level is a project undertaken by Feliciano Montoya Bello, Director of Civil Protection in San Felipe, Yucatan. Based on information compiled between 2001 and 2015, Montoya prepared a risk map identifying the main hazards and risks the town faced. The map is a graphic representation of local historical knowledge of the region in which risks are identified with unique symbols. 
It shows events that have affected San Felipe in the past - hurricanes, hail, flooding, red tide, lionfish (a venomous fish originally native to the Indo-Pacific which has begun to thrive around Caribbean coastal regions), nortes, fires, deforestation, drought, epidemics, pests, ocean pollution and human activities (see Fig. 2).

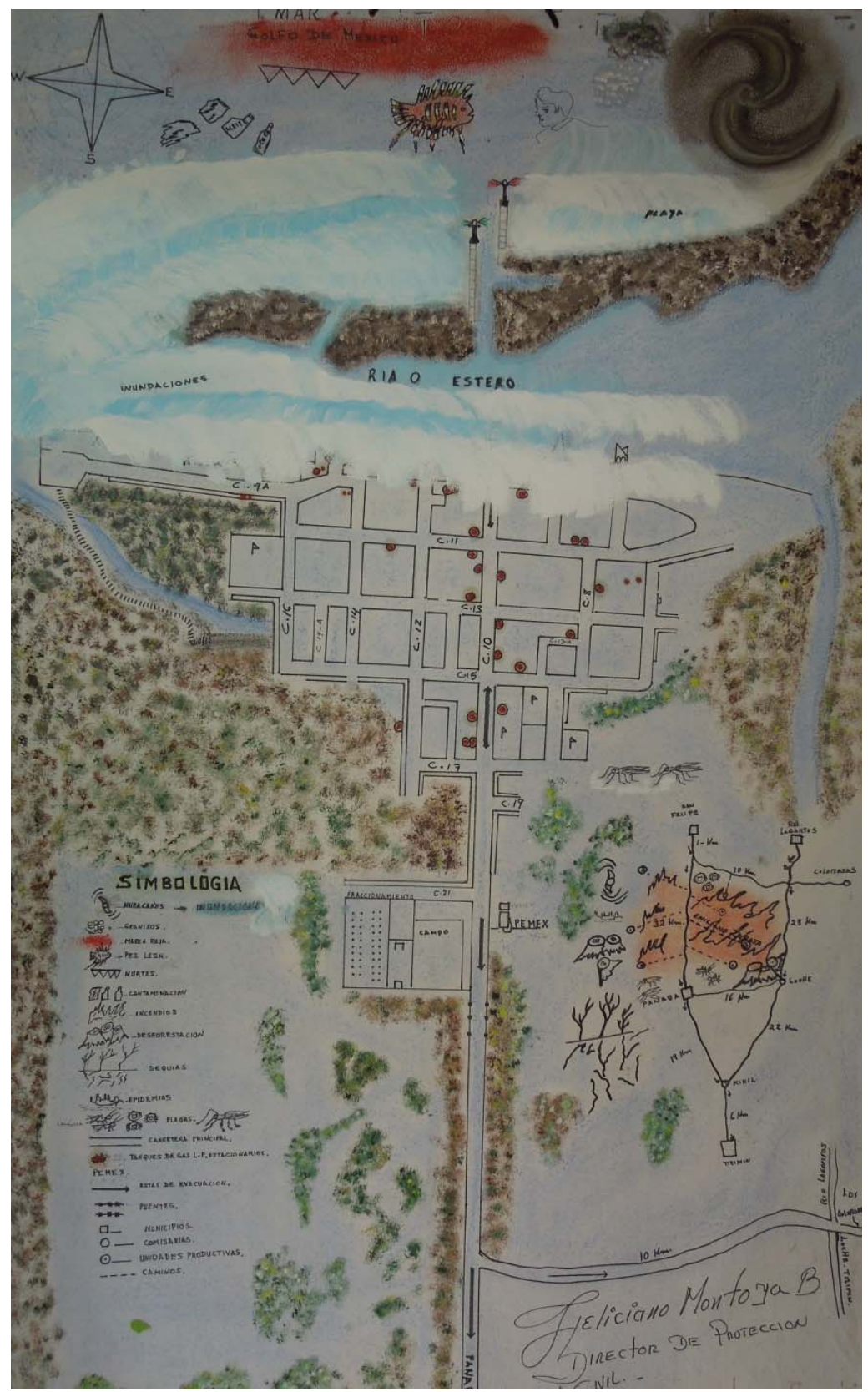

Figure 2: Risk map, San Felipe Yucatan, Mexico. (Source: Feliciano Montoya Bello, 2015.) 
This type of interpretation of events, carried out by inhabitants from the site where the phenomenon occur, is highly valuable, because strategies for integral adaptation are developed better when taking into account specific threats and hazards. Government participation is crucial in monitoring what the experts say, but equally important are the observations of those in charge of civil protection at the local level. It is not enough to issue proposals on evaluating and managing the risk of climate change, without learning about the problems at the local level, and transmitting the experiences gathered to intervene and develop the right strategies for integral adaptation, to the benefit of those that are directly affected.

\section{RIA LAGARTOS BIOSPHERE RESERVE: OPPORTUNITIES AND LIMITATIONS} Identifying opportunities that might benefit at-risk localities is a complex task, because these opportunities may be temporary, and the benefits only short-term.

According to Ferrero and Gargantini [19], disasters should not be considered a source of opportunity, but they are admittedly essential to certain official initiatives to improve conditions in areas such as infrastructure, housing and nutrition, among others. The opportunities that a community might exploit and develop should be included in strategies not just at the government level, but at the local community level. Opportunities may include improved alimentary security, property, quality of life, access to jobs and thus to higher income, not just for the poorest members of the community but for all productive sectors.

Table 1: Opportunities and limitations. Ría Lagartos Biosphere Reserve, Yucatan, Mexico, 2016. (Source: Prepared by author based on interviews.)

\begin{tabular}{|l|l|l|l|l|l|}
\hline \multicolumn{3}{|c|}{ Opportunities } & \multicolumn{3}{c|}{ Limitations } \\
\hline Economic & Social & Environmental & Economic & Social & Environmental \\
\hline $\begin{array}{l}\text { Job } \\
\text { opportunities }\end{array}$ & Gender equality & $\begin{array}{l}\text { Natural } \\
\text { resources }\end{array}$ & $\begin{array}{l}\text { Limited } \\
\text { productive } \\
\text { sector }\end{array}$ & $\begin{array}{l}\text { Educational: } \\
\text { Training for } \\
\text { local people }\end{array}$ & $\begin{array}{l}\text { Ría Lagartos } \\
\text { Biosphere } \\
\text { Reserve }\end{array}$ \\
\hline Higher income & $\begin{array}{l}\text { Cultural } \\
\text { heritage }\end{array}$ & $\begin{array}{l}\text { Egalitarian } \\
\text { fishing }\end{array}$ & $\begin{array}{l}\text { Distance from } \\
\text { closest city }\end{array}$ & $\begin{array}{l}\text { Social } \\
\text { organization }\end{array}$ & $\begin{array}{l}\text { Hydro- } \\
\text { meteorological } \\
\text { phenomena }\end{array}$ \\
\hline Nutrition & Education & $\begin{array}{l}\text { Timely } \\
\text { information on } \\
\text { Reserve } \\
\text { management }\end{array}$ & $\begin{array}{l}\text { Low wages in } \\
\text { sources of } \\
\text { employment }\end{array}$ & $\begin{array}{l}\text { Gender } \\
\text { inequality }\end{array}$ & $\begin{array}{l}\text { Red tide, } \\
\text { hurricanes, } \\
\text { epidemics, } \\
\text { pests, coastal } \\
\text { erosion }\end{array}$ \\
\hline $\begin{array}{l}\text { Access to } \\
\text { health }\end{array}$ & $\begin{array}{l}\text { Social } \\
\text { organization }\end{array}$ & $\begin{array}{l}\text { Access to } \\
\text { public } \\
\text { programs }\end{array}$ & & $\begin{array}{l}\text { Use of non- } \\
\text { traditional } \\
\text { technologies }\end{array}$ \\
\hline $\begin{array}{l}\text { Dignified } \\
\text { housing }\end{array}$ & $\begin{array}{l}\text { Local know- } \\
\text { how }\end{array}$ & $\begin{array}{l}\text { Conservation } \\
\text { of local } \\
\text { techniques }\end{array}$ & & & \\
\hline
\end{tabular}


Opportunities must be identified in the towns of San Felipe, Río Lagartos, El Cuyo and Coloradas, but there are also limitations that stand in the way of inhabitants' further development.

Like the opportunities, these limitations can generally be categorized as economic, social and environmental (see Table 1).

The success of integral adaptation and disaster risk reduction in any locality will depend on the local people's access to opportunities. External circumstances may improve or impede their ability to deal with the situation. The functioning of the environment of the Ría Lagartos Biosphere Reserve is determined mainly by laws governing the natural resources on which inhabitants depend for their social dynamic and quality of life.

Finally, in identifying environmental strategies, we took into account indicators on environmental conditions in the towns included in the Ría Lagartos Biosphere Reserve. One of these is the supply of fresh water, which is a basic resource, but limited in these towns by contamination of cenotes (wide, deep naturally generated freshwater wells) and the use of agro-chemicals. Because tourism to this area is infrequent, governments have little incentive to pursue strategies such as the installation of wastewater treatment plants, which make the area of the Reserve more vulnerable because of the sewage generated by homes and shops. Wastewater drains directly into the river without any prior treatment. The high price of wastewater treatment systems, lack of appropriate facilities for moving waters on an urban level, and the lack of basic drainage in private homes, limits the community's development and triggers a set of other problems.

On the matter of transport, one common problem in these areas is the use of fuel-powered boats. Many are not in optimum working condition and are thus more likely to pollute river waters. Considering that river fishing is the means of livelihood for most of the population, sustainable technologies are urgently needed to reduce the risk of pollution from the use of boats (see Fig. 2).

There are five villages on the Yucatan peninsula whose populations depend mainly on fishing activity: Celestun, Dzilam de Bravo, El Cuyo, Progreso, Río Lagartos, San Felipe Sisal and Telchac. Of these, only San Felipe, Río Lagartos and El Cuyo are part of the Ría Lagartos Biosphere Reserve. Between 2006 and 2014, all three of these saw an increase in fishing production (counting only their most popular species - lobster, grouper, red snapper, sea cucumber and octopus). In Río Lagartos, fishing production totaled 1622.37 metric tons

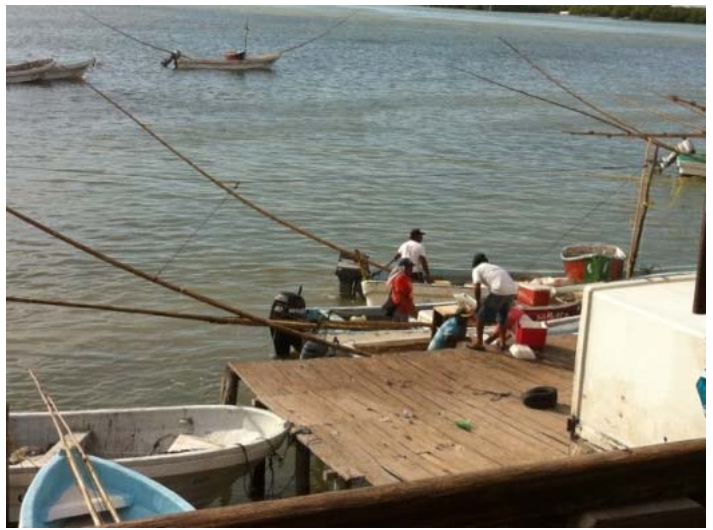

Figure 3: Fisherman on the Lagartos River, Yucatan, Mexico, 2016. (Source: Nelly Cabrera.) 
in 2014, followed by San Felipe, with 953.59 metric tons, and finally El Cuyo, with 860.97 metric tons. For comparative purposes, the largest fishing port in Yucatan, which is Progreso, produced 8548.16 metric tons of fish. This is in an indication of the limitations posed by traditional fishing in the villages located within the Biosphere Reserve.

The characteristics of a Biosphere Reserve pose certain limitations on inhabitants, whose situation is further complicated by social, economic and environmental limitations, and the frequency of hydrometeorological and mad-made risks.

Another aspect the population has identified as a specific concern is housing. Here, the idea that a disaster can afford certain opportunities is illustrated well, because reconstruction efforts can lead to better living conditions for local communities. This was not the case in these villages, however. After hurricane Isidro hit in the Yucatan peninsulas in 2002, the National Disaster Fund (FONDEN) was applied to remedy the effect of widespread flooding and destruction of homes by winds topping $220 \mathrm{~km} /$ hour. But the FONDEN proposal did not take into account the characteristics of traditional housing in the coastal region, nor the preservation of local materials. The proposals on roofing and other materials were incompatible with the region and with the type of housing, and no follow-up was given to maintaining traditional homes after the repairs.

Specifically, the standard FONDEN home, built with brick walls and reinforced concrete flooring, is not ideal for the coastal climate, and in fact is close to uninhabitable in a region where temperatures range from $36^{\circ} \mathrm{C}$ in May to $16^{\circ} \mathrm{C}$ in January. Traditional housing is built using zapote wood walls, a traditional wood structure and guano palm covering, which keeps the dwelling at a more comfortable temperature for occupants.

It is urgent that strategies be developed to structurally reinforce and improving traditional coastal housing to make it more hurricane-resistant and protect the local communities' property in these circumstances. These strategies should avoid altering the traditional use of the materials, and instead rely on the conservation of traditional construction techniques in order to improve housing's use, durability and conservation.

In fact, incorporating materials that are incompatible with the region (concrete flooring, cardboard or galvanized metal roofing, brick walls) may actually increase the vulnerability of coastal zones, because it represents a forced adaptation to climate change based on the imposition of non-functional housing programs. These are mere short-term solutions that over time result in uninhabitable spaces that eventually end up being used for storage, which was not their intended purpose.

Government housing policy is embodied in Yucatan State Housing Agency programs such as Vivienda Digna, Casa Universal, Casa Digna and Vivienda Digna (special category) [20], but these serve only residents with proven income, leaving those without a formal job unprotected.

\section{CONCLUSIONS}

The lack of programs and policies that satisfy the primordial needs of the population heightens vulnerability to natural phenomena. Failures to involve local inhabitants in decision-making in an equitable and organized way to improve the social fabric complicates the task of integral adaptation to climate change. Encouraging social participation and gender equity in decision-making in the most vulnerable communities improves the social response of the population.

Information on the problem of disasters, vulnerability and risk for the communities of the Ría Lagartos Biosphere Reserve should be available for all the population in simple language, and scientific knowledge should be exchanged for local knowledge. This would allow for a 
more integral adaptation to climate change, and the development of policy opportunities to protect local livelihoods in coastal zones.

The strategies identified should be aimed primarily at improving and introducing innovative means of subsistence to reduce the vulnerability of local populations and improve their economic development and income levels. Essentially, the men and women of the Ría Lagartos Biosphere Reserve need access to a more diverse array of productive and labor opportunities. Furthermore, conservation of traditional homebuilding techniques in the region should be an essential part of sustainability strategies applied to help local inhabitants deal with the effects of climate change.

\section{ACKNOWLEDGEMENT}

Thanks to the Instituto Politécnico Nacional ESIA TEC for the support received in the Research Project No. SIP 20161627.

\section{REFERENCES}

[1] IPCC, Managing the risks of extreme events and disasters to advance climate change adaptation. A Special Report of Working Groups I and II of the Intergovernmental Panel on Climate Change, eds C.B. Field et al., Cambridge University Press: Cambridge, UK and New York, 582 pp., 2012.

[2] The United Nations Office for Disaster Risk Reduction (UNISDR), https://www.unisdr.org/we/coordinate/global-platform. Accessed on: 19 Aug. 2016.

[3] World Conference on Disaster Risk Reduction, 18-22 Jan. 2005, Kobe, Hyogo, Japan. Hyogo Framework for Action 2005-2015: Building the Resilience of Nations and Communities to Disasters. Extract from the report of the World Conference on Disaster Risk Reduction (A/CONF:206/6) Online. www.eird.org/cdmah/contenido/hyogoframework-spanish.pdf. Accessed on: 29 Aug. 2016.

[4] United Nations, Sendai Framework for Disaster Risk Reduction 2015-2030. http://www.unisdr.org/we/inform/publications/43291. Accessed on: 29 Aug. 2016.

[5] The World Bank, Working for a world free of poverty. http://wdi.worldbank.org/table/2.1\#. Accessed on: 29 Aug. 2016.

[6] Cannon, T., Vulnerability analysis and the explanation of "natural disasters". Disasters, Development and Environment, ed. A. Varley, John Wiley, 1994.

[7] Maskrey, A., Compiler. Los desastres no son naturales. 1993. LA RED. http://www.desenredando.org/public/libros/1993/ldnsn/. Accessed on: 3 Aug. 2016.

[8] Wisner B., Blaikie, P., Cannon, T. \& Davis, I., At Risk: Natural Hazards, People's Vulnerability and Disasters, 2nd ed., 2003.

[9] Política Nacional de Mares y Costas de México, Gestión integral de las regiones más dinámicas del territorio nacional. http://digaohm.semar.gob.mx/. Accessed on: 16 Aug. 2016.

[10] Programa Especial de Cambio Climático, 2014-2018, Mexico, 2013. www.semarnat. gob.mx/.../programa_especial_de_cambio_climatico_2014-2018.pdf. Accessed on: Aug. 2016.

[11] National Institute for Ecology and Climate Change (INECC), SEMARNAT, 2015. http://www2.inecc.gob.mx/publicaciones2/libros/130/yuc.html. Accessed on: Aug. 2016.

[12] Cardona, A. \& Omar, D., Indicadores de riesgo de desastre y de gestión de riesgos: Programa para América Latina y El Caribe / informe resumido. 2007. Banco Interamericano de desarrollo. www.iadb.org/sds/env 
[13] Wilches-Chaux, G., La vulnerabilidad global. Los Desastres no Son Naturales, A. Maskrey (compiler), LA RED, Red de Estudios Sociales en Prevención de Desastres en América Latina, Colombia, 1993. http://www.desenredando.org/public/libros/ 1993/ldnsn/. Accessed on: 9 Aug. 2016.

[14] Fekete, A., Hufschmidt, G. \& Kruse, S., Benefits and challenges of resilience and vulnerability for disaster risk management, 2014. Disaster Risk. www.springer.com/13753. Accessed on: 9 Aug. 2016.

[15] Soares, D. et al., Vulnerabilidad y adaptación en Yucatán: un acercamiento desde lo local y con enfoque de equidad de género, Instituto Mexicano de Tecnología del Agua: Jiutepec, México, 2014.

[16] Busso, G., Vulnerabilidad social: nociones e implicaciones de politicas para Latinoamérica a inicios del siglo XXI, 2001. CEPAL, Seminario Internacional: Las diferentes expresiones de la vulnerabilidad social en América Latina y el Caribe, CEPAL, CELADE - División de Población: Santiago, Chile.

[17] Macías, J.M., Significado de la vulnerabilidad social frente a los desastres. Revista Mexicana de Sociología, 54(4), pp. 3-10, 1992.

[18] Audefroy, F.J., Haiti: Post-earthquake lessons learned from traditional construction. Environment \& Urbanization, International Institute for Environment and Development (IIED), 23(2), pp. 447-462, 2011.

[19] Ferrero, A. \& Gargantini, D., El riesgo como oportunidad. Revista INVI, 2003. http://www.redalyc.org/articulo.oa?id=25804707. Accessed on: 16 Aug. 2016.

[20] IVEY, Instituto de Vivienda del Estado de Yucatán, 2012-2018. http://www.ivey.yucatan.gob.mx/ 